\title{
回収・再使用可能なガラス容器の耐内圧及び 耐熱衝撃特性について
}

\author{
横倉 修一 \\ （麒麟麦酒（株）富田製丵工場）
}

我が国において従来より最も広く使用されているリターナブル（回収，再使用可能）のガラス容 器の一つを選び，その破壞強度につき，主として耐内圧強度，耐熱衝撃強度及び耐熱圧強度（内圧 及び熱衝撃を同時に加えた場合の破壞強度）を取り上げ，強度の経年劣化に関する検討を行い，ま たこれらの強度特性について若干の弾性力学的な考察を加えた. 実験結果を要約して以下に示す.

1）本実験に使用したガラスびん（胴径 $75 \mathrm{~mm}$, 肉厚 $3 \sim 4 \mathrm{~mm}$ ) においては，市場において使 用を開始して約 $3 \sim 4$ 年間で強度の急激な低下をきたし, それ以降では緩慢な低下に推移した.

2）びんに水圧を加えて破壊させる耐内圧強度においては破壊起点は表面傷の集中的に発生して いる円筒部に集まっており，必ずしも肉厚の薄い位置に集中することはなかった。 またびん破壊時 の内圧 $(P)$ と破壊起点から伸びた割れ目の分岐するまでの長さ $(L)$ の閒には，大まかに $P \cdot L^{0.48} \doteqdot$ 81 (一定) なる関係が認められた。

3）びんに水圧と熱衝撃を同時に加えて破壊させる耐熱圧強度においては，びん破壊時における 内圧と熱衝撃值（急冷による温度差）の間には直線関係のあることが分った。

(1983 年 1 月 13 日受付)

\section{Internal Pressure and Thermal Shock Resistance of Returnable Glass Containers}

\author{
Shuichi YOKOKURA \\ $\left(\begin{array}{l}\text { Kirin Brewery Co., Ltd., Tonda Bottle-Manufacturing Plant } \\ \text { 4473-4, Ooaza-Tonda, Shin-Nanyou-shi, Yamaguch } 746\end{array}\right)$
}

The strength degradation test of returnable glass bottles was carried out over ten years with emphasis on the bursting strength, thermal shock resistance, internal pressure-thermal shock strength and so forth. The results obtained are summarized as follows:

1) The strength of bottles decreased rapidly during the first three or four years and level off.

2) In bursting strength test, the fracture origin was dependent significantly on the degree of ellipticity of the side wall, and the relationship between the internal hydraulic pressure $P\left(\mathrm{~kg} \cdot \mathrm{cm}^{-2}\right)$ and the length of crack developed to the branch point $L(\mathrm{~cm})$ was given by the following equation, $P \cdot L^{0.48} \div 81$

3) When the internal pressure and thermal shock were applied simultaneously to the bottles, a linear relationship was obtained between the internal pressure and the thermal shock (temperature difference) at the bottle breakage.

Furthermore, pattern of fracture, situation of fracture origin, distribution of tensile strain have been investigated. Based on the experimental results elasto-mechanical analysis has been developed.

[Received January 13, 1983]

Key-words : Glass container, Bursting strength, Thermal shock resistance, Wall thickness, Surface crack 


\section{1. 緒言}

ガラスびんの破壊強度特性については，これまでにか なりの報文1 ${ }^{10)}$ はあるが，そのほとんどが表面傷のほ とんぞない新しいびんを対象として検討されたものであ り，市場で繰り返し使用され，表面傷の発生しているリ ターナブルびんの破壊強度特性についてはいたって文献 が少ない ${ }^{111}$.

ところで新びんにおいてはびん形状及び外径, 肉厚等 の諸元から, 応力解析によりびん強度, 破壞起点等をあ らかじめ大まかに推定し得るが，一方市場で繰り返し回 収して使用されるリターナブルびんにおいては，これら のびん強度, 破壊起点等が表面傷に大きく依存してお り，新びんの場合とはかなり異なった特性がみられてい る.

ところでリターナブルびんの破壊強度特性に関する報 文がこれまでに非常に少ない原因としては，びん表面に 発生する傷の形状, 深さなどを的確に測定し得る方法が 見いだされていない点, 傷の性状とびんの強度の関係が 定量的に充分把握されていない点等を挙げることができ る $^{122}$.

そこで本報告においては表面傷の発生しているリター ナブルびんを対象として，強度の経年劣化，破壞パタ一 ン, 破壊起点の位置, 破面観察等を中心とした検討を行っ た. 試料びんとしては我が国において従来から最む広く 使用されているリターナブルびんの一つとして, 内容積 $658 \mathrm{~cm}^{3}$, 胴径 $75 \mathrm{~mm}$, 肉厚約 $4 \mathrm{~mm}$ のものを選んだ.

ところでびん強度については従来より耐内圧強度及び 耐熱衝撃強度が主要な試験法とされているが, これらの 試験法はそれぞれ独立して検討されてきたようである.

ところが内圧あるいは熱衝撃のみが原因で, 市場でび んが破壊するケースは少なく, 破壊時にガラス片が飛散 する危険のある炭酸飲料びんにおいては, 内圧負荷下で の熱衝撃が問題なのであり，充てん工場での熱殺菌ある いは夏期にびんを急冷するなど, 市場における破びん事 故との関係で問題となるわけである.

そこで著者はびんに内圧をかけた状態下で熱衝撃を加 えて破壊させる “耐熱圧強度”（本報告においては仮り に呼ぶことにする) の試験法を検討したので，従来の耐 内圧強度, 耐熱衝撃強度とともに報告する.

Table 1. Weight and wall thickness of test bottles.

\begin{tabular}{|c|c|c|c|c|c|c|c|}
\hline Sample & $\begin{array}{l}\text { Number of } \\
\text { sample } \\
(n)\end{array}$ & $\begin{array}{c}\text { Wieight } \\
(\mathrm{g})\end{array}$ & $\begin{array}{l}15 \mathrm{~mm} \\
\text { from } \\
(\mathrm{X})\end{array}$ & $\begin{array}{l}\text { Wall } \\
\text { high } \\
\text { the }\end{array}$ & $\begin{array}{l}\text { thickn } \\
\text { bottom } \\
(\sigma)\end{array}$ & $\begin{array}{l}\text { ss }(\mathrm{mm}) \\
140 \mathrm{~mm} \\
\text { from } \\
(X)\end{array}$ & $\begin{array}{l}\text { high } \\
\text { the bottom } \\
(c)\end{array}$ \\
\hline A & 50 & 575 & 5.0 & & 0.35 & 3.7 & 0.30 \\
\hline B & 50 & 605 & 4.7 & & 0.32 & 4.0 & 0.28 \\
\hline
\end{tabular}

Note: 1) Sample B consists of bottles with knurls on the surface of the upper sidewall.

2) $\mathrm{X}$ : Average $\sigma:$ Standard deviation

\section{1 試料びんの概要}

\section{2. 実 験 方 法}

本実験に使用したガラスびんは，従来より我が国にお いて最も広く使用されているびん種の一っであり，形状 及び内容積が同一であって，肉厚が異なる 2 種類（A及 びB）を用いた。なおびん形状及び諸元を図 1 及び表 1 に示す.

試料びんは市場での使用期間が長くなるに從って,び 几外表面の加傷が進行し，円筒下部（底より約 $15 \mathrm{~mm}$ 高さの領域) 及び円筒上部（底より約 $140 \mathrm{~mm}$ 高さの 領域）で管径が $0.1 \sim 0.2 \mathrm{~mm}$ 程度他の部分の管径より 大きい形状となっているため, この二つの領域に表面傷 が集中する傾向にあり，またこれらの領域はびん破壊時 に最も破壊起点となりやすいところでもある.

試料びんについて，まず試料（A）は市場より製造年 度別に無作為に採取し，実験洔特に付記がないかぎりび ん強度の安定している, 使用年数 7 10 年のびんを使用 した.

試料（B）製びん工場で吹製直後の新びん（表面傷 がほとんど発生していない）を用い，下記の 2.6 節に示 す方法でびん表面を加傷して試料びんとして調製した. また試料（B）には表面傷の集中する円筒上部にナーリ ング処理（外部からの衝撃に対する応力緩和を目的とし て, 高さ $0.1 \mathrm{~mm}$ 程度の粒粒状の突起を施すこと）が なされており，またびん重量及び肉厚分布においても試 料 (A) とは若干異なっている.

\section{2 肉厚分布}

びん底より所定高さを円周方向にダイヤモンド・カッ ターにより輪切り状に切り出し, ダイヤル・キャリパス により肉厚測定を行った. なお肉厚は輪切り片の円周上

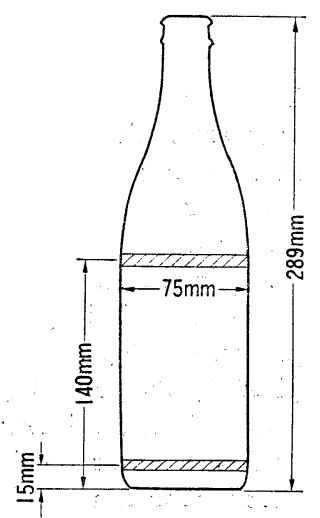

Fig. 1. Schematic illustration of a test bottle.

(Note) (1) Inner volume : $658 \mathrm{~cm}^{3}$ Weight $: 575 \mathrm{~g}$ and $605 \mathrm{~g}$

(2) Hatched parts indicate heavily abraded area during bottle use. 
を等間隔に 8 か所測定し，その平均值をもって表示し た.

試料の肉厚分布をみると表 1 から明らかなように，肉 厚はびん底部が最も厚く，円筒部の表面傷帯においては 下部（15 mm 高さ）の方が上部（140 mm 高さ）に比べ てかなり厚い形状となっている. また $40 〜 140 \mathrm{~mm}$ 高 さの円筒部の領域では肉厚はほぼ等しいと考えてよい.

\section{3 酎内圧強度試験}

びんに内圧を加えて破壊させる装置 ${ }^{13)}$ (アメリカン・ グラスリサーチ社製，インクレメント・プレッシャーテ スター，1200-Dual Head Type）を用いて試料を破壊 させ，びん破壊時の加圧を 1 分間持続の耐 内 圧強度 ${ }^{14)}$ $\left(\mathrm{kg} \cdot \mathrm{cm}^{-2}\right)$ として表示した.

また内圧によりびん外表面に発生するひずみについて はストレインゲージをびん表面の円周方向に張り付け, 動ひずみ計（共和電業社製, CDV-110 A 型) により測 定した. なおストレインゲージは共和電業社製（KFC03-C1-11，抵抗 $120 \Omega$, ゲージ・ファクター 2.21, ゲ ージ長さ $0.3 \mathrm{~mm}$ ) を用いた. なお内圧あるいは熱衝撃 によるびん破壞時の破面観察を行うと, 破壊起点からの 割れ目の進行方向が垂直方向（たて割れ）であるケース が圧倒的に多く，また内圧負荷時にびん外表面に発生す る引っ張りひずみ分布を測定してみると, 円周方向の方 が垂直方向よりも大きいため，本実験においては円周方 向に発生する引っ張りひずみに限定して検討することと した ${ }^{8), 16), 17) . ~}$

\section{4 耐熱衝撃強度}

\section{（1）急冷による熱衝撃}

ASTM (American Society for Testing Materials) C149-77 に準じて実験を行った. すなわちびんをまず所 定温度に設定された温水槽に $1 \mathrm{~h}$ 浸漬させた後, 冷水槽 $\left(10^{\circ} \mathrm{C}\right.$ 一定に設定）へ移し，びん外表面に急冷による熱 衝撃を与え，びんが全数破壊するまで温水槽を $3^{\circ} \mathrm{C}$ 間隔 で段階的に昇温させていくプログレシブ・テスト法を採 用した。

\section{（2）急熱による熱衝撃}

びんを冷水槽 $\left(10^{\circ} \mathrm{C}\right.$ 一定) に $1 \mathrm{~h}$ 浸漬させた後，所 定温度に設定されている温水槽へ移し，びん外表面に急 熱による熱衝撃を与え, 急冷の場合と同じく, 温水槽を 段階的に昇温させていくプログレッシブ・テスト法を採 用した。

\section{5 耐熱圧強度}

びんに水を充てんした後，びんロ部にナイロン製耐圧 導管を取り付け，それにプランジャー・ポンプを連結し た状態でびんを温水槽に $1 \mathrm{~h}$ 浸漬した後, プランジャー ・ポンプの稼働により耐圧導管から加圧水を送り込み, びんに所定の内圧を加えて $30 \mathrm{~s}$ 経過した後, 冷水槽 (10 ${ }^{\circ} \mathrm{C}$ 一定）へ移動させ，びん外表面に熱衝撃を与え，温水
槽を同じく $3{ }^{\circ} \mathrm{C}$ 間隔で段階的に昇温させていくプログレ ッシブ・テスト法を採用し，びん破壊時の内圧及び温度 差を測定した. なお，びん内圧の調整は接点圧力計を用 い，電磁弁による自動制御方式をとった.

\section{6 ひんの加傷方法}

市場より回収びんを採取する場合を除いて，新びん （表面傷がほとんど発生していない）を人為的に加傷す る場合はびん加傷機 ${ }^{15)}$ (アメリカン・グラスリサーチ社 製，ラインシミュレーター）を用いてて行った. この加傷 機は回転円板及び円板外周に沿って設けられた円形状の 送びんガイドから構成されており，水の充てんされたび ん 22 本をガイドに沿って単列状に並べ, 円板を回転さ せることにより, 速度 $50 \mathrm{~m} / \mathrm{s}$ でびんを円板上に送行さ せて，びん同士で押し合い，衝撃等を与えて外表面を加 傷させる装置である.

\section{3. 結果並びに考察}

\section{1 耐内圧強度}

試料 (A) について耐内圧強度の経年劣化に関する検 討を行った. その結果を図 2 に示す. 図 2 から明らかな ように使用を開始して, 約 $3 \sim 4$ 年間で急激な強度低下 をきたし，それ以降では緩慢な低下に推移した. ところ で現在世界各国で使用されているリターナブルのガラス びんは管径 $70 \sim 75 \mathrm{~mm}$, 肉厚 $3 \sim 4 \mathrm{~mm}$ 程度のものが 圧倒的に多いところから，本実験によるリターナブルび んの強度低下パターンはかなり一般性があると考えられ る. 次にびんの破壞起点を観察すると円筒上部（底より 約 $140 \mathrm{~mm}$ 高さの位置）の外表面に集中しており，こ の領域は表面傷が集中的に発生している領域に対応して いた.

次にびんの破壊パターンに注目し，クラックの長さ （破壊起点から出発したクラックが分岐するまでの単 線 区間の長さ（図 3 参照）と耐内圧強度の関係について検 討を行った.その結果は図 4 に示す. 図 4 から明らかな

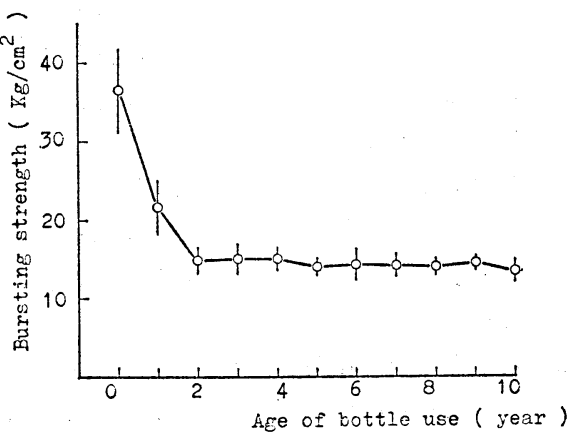

Fig. 2. Relationship between age of bottle use and the bursting strength.

Points show average values and bars show standard deviations $(n=20)$. 

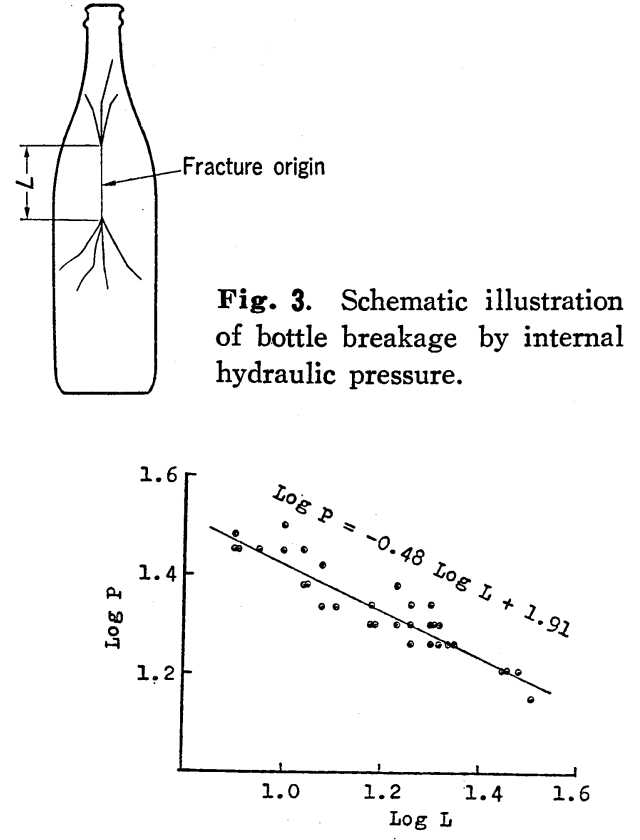

Fig. 4. Relationship between internal pressure $(P)$ and length of crack $(L)$ depicted in Fig. 3 $P$ : Internal pressure $\left(\mathrm{kg} / \mathrm{cm}^{2}\right), L$ : Length of crack developed to the branch point $(\mathrm{cm})$.

ように耐内圧強度 : $P\left(\mathrm{~kg} \cdot \mathrm{cm}^{-2}\right)$ が高いほどクラック 長さ：L $(\mathrm{cm})$ が短くなる傾向にあり， $P$ と $L$ の間に は以下のような関係が認められた.

$\log P+0.481 \log L=1.907$

この関係は近似的にみれば，以下の式とみてよい.

$P \cdot L^{0.48} \doteqdot 81$

この関係式はガラスの破壊応力 $(\sigma)$ と破壊起点におけ る鏡面半径 $(r)$ の間に成立する, $\delta \cdot r^{1 / 2}=c(c$ :一定 $)$ なる関係式 ${ }^{18)}$ に類似していることは注目される.

次に破壊起点における肉厚について測定を行った. そ の結果を表 2 に示す. 表 2 から明らかなように破壊起点 は必ずしも肉厚の薄い位置に集中していなかった.

そこで破壊起点が位置するびん円筒部を円周方向に輪 切り状に切断し, 輪切り面から棈円度（真円からのずれ の度合いであり，一般に長径 (75 mm で一定) と短径 の差として定義されている）に注目してみると, 破壊起 点はいずれも短径部 (管径が最も小さく, かつ曲率半径 (円筒の) が最も大きい位置に対応する）に集中してい ることが分った.

そこで内圧負荷時に棈円度の度合いがびん円筒部に発 生するひずみ量に及ぼす影響について，ストレインゲー ジを用いて検討を行った. その結果を図 5 に示す.

なお試料びん（A）においては，円筒部が真円状であ れば円筒の曲率半径 (内表面) は約 $33.8 \mathrm{~mm}$ (筒径 75 $\mathrm{mm}$, 肉厚約 $3.7 \mathrm{~mm}$ として) であるが, 現在業界で
Table 2. Measurement results of wall thickness (Sample B).

\begin{tabular}{lccc}
\hline Wall thickness & $\begin{array}{c}\text { Sample } \\
(\mathrm{n})\end{array}$ & $\begin{array}{c}\mathrm{X} \\
(\mathrm{mm})\end{array}$ & $\begin{array}{c}\sigma \\
(\mathrm{mm})\end{array}$ \\
\hline Maximum thickness & 40 & 4.95 & 0.30 \\
Minimum thickness & 40 & 3.60 & 0.30 \\
Average thickness & 40 & 4.06 & 0.27 \\
Origin of breakage & 40 & 4.13 & 0.37 \\
\hline
\end{tabular}

(Note) X: Average

б: Standard.deviation

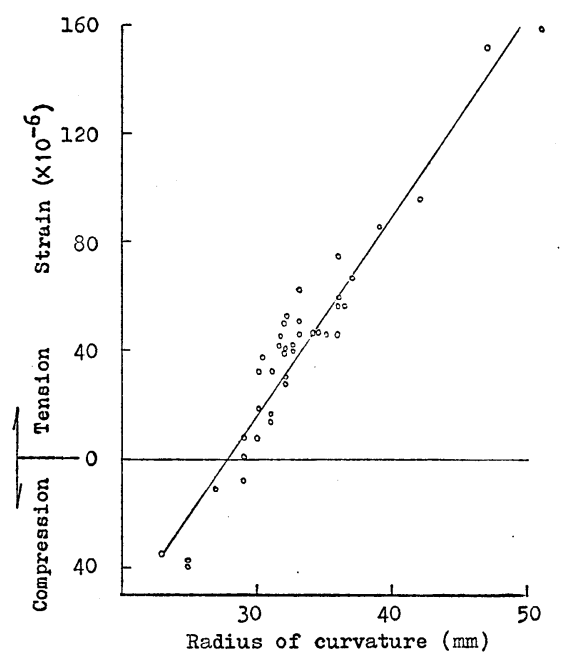

Fig. 5. Relationship between radius of curvature and circumferential strain of sidewall at inner pressure of $4 \mathrm{~kg} / \mathrm{cm}^{2}$.

(Note) Radius of curvature of inner cylindrical sidewall near the fracture origin was measured with a compass.

は棈円度の許容範囲は $2 \mathrm{~mm}$ 程度とされている. いま 棈円度 $2 \mathrm{~mm}$ の場合を考えてみると，それに対応する短 径部の曲率半径 (内表面) は約 $37.2 \mathrm{~mm}$ であり,ひず み量は図 5 から約 $80 \times 10^{-6}$ であることが分る. また真 円状 (曲率半径 $33.8 \mathrm{~mm}$ ) でのひずみ量は約 $50 \times 10^{-6}$ であるから,楕円度の影響はかなり大きいと考えられる。

したがってびん円筒部の楕円度は耐内圧強度を論ずる らえで重要な要素の一つと考えてよい.

\section{2 耐熱衝撃強度}

\section{（1）急冷による熱衝撃}

試料 (A) について急冷による耐熱衝撃強度の経年劣 化に関する検討を行った. その結果を図 6 に示す. 図 6 から明らかようにこの強度の劣化傾向は耐内圧強度に類 似したパターンを示しており，破壊起点はびん円筒下部 （底より約 $15 \mathrm{~mm}$ 高さ付近）に集中していた. また，こ の位置は表面傷の集中する位置に対応していた.

次に破壊パターンをみると図 7 に示すようにき裂の数 が 1 ～本程度と少なく, 破面が平滑であることが特徴 であり，き裂は縦方向へほぼ直線状に長く伸びており， 
Table 3. Results of the thermal shock test (from low temp. to high temp.).

\begin{tabular}{cccccc}
\hline $\begin{array}{c}\text { Sample } \\
(\mathrm{n})\end{array}$ & $\begin{array}{c}\text { iater bath } \\
(\text { low temp. }) \\
\left({ }^{\circ} \mathrm{C}\right)\end{array}$ & $\begin{array}{c}\text { iater bath } \\
(\text { high temp. }) \\
\left({ }^{\circ} \mathrm{C}\right)\end{array}$ & $\begin{array}{l}\text { Temp. } \\
\text { difference }\end{array}$ & $\begin{array}{l}\text { Thermal } \\
\text { shock } \\
\text { (times) }\end{array}$ & $\begin{array}{c}\text { Breakage } \\
(\mathrm{n})\end{array}$ \\
\hline 56 & 10 & 70 & 60 & 30 & 0 \\
56 & 10 & 75 & 65 & 30 & 0 \\
56 & 10 & 80 & 70 & 20 & 0 \\
56 & 10 & 85 & 75 & 20 & 0 \\
56 & 1 & 76 & 75 & 1 & 0 \\
56 & 1 & 81 & 80 & 1 & 0 \\
56 & 1 & 86 & 85 & 1 & 0 \\
56 & 1 & 91 & 90 & 1 & 0 \\
56 & 1 & 96 & 95 & 1 & 0 \\
\hline
\end{tabular}

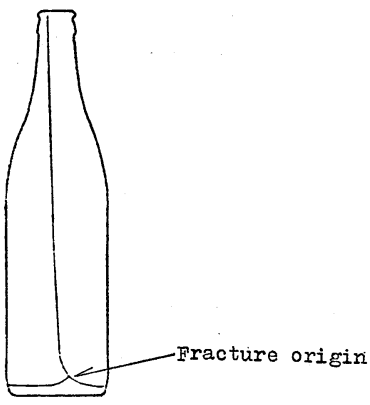

Fig. 7. Schematic illustration of bottle breakage by thermal shock.

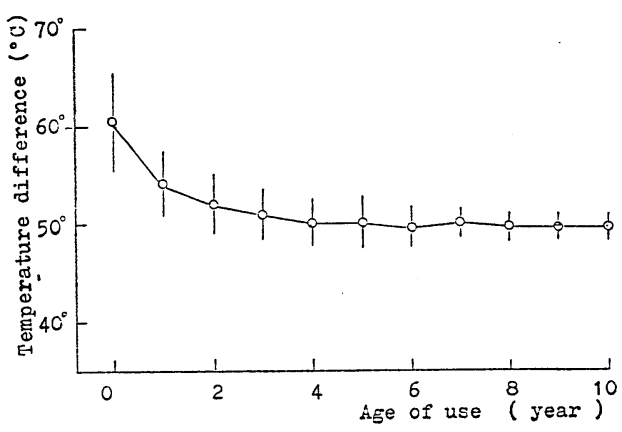

Fig. 6. Relationship between age of bottle use and the thermal shock strength.

Points show average values and bars show standard deviations $(n=40)$.

熱衝撃を受ける円筒部外表面の主応力方向が円周方向で あることを示している.

\section{（2）急熱による熱衝撃}

試料（A）について急熱による熱衝撃を与えた場合に ついて検討を行った. その結果を表 3 に示す. 温度差と して最高 $95^{\circ} \mathrm{C}$ まで熱衝撃を与えたが，びんは全く破損 しなかったところから，急熱による熱衝撃については日 常の取り扱いで破壊する危険は非常に低いと考えられ る.

なお急熱による熱衝撃では，引っ張りひずみがびんの 内表面に発生することになるが，内表面に発生する傷は 洗びん工程での内洗ブラシ, 充てん工程でのフィラー・ チューブなどとの接触による軽微なものと考えられ，外 表面に温度差 $95^{\circ} \mathrm{C}$ 程度の熱衝撃を与えても強度的には 充分耐え得ることを示している.

\section{3 耐熱圧強度}

\section{（1）基本特性の検討}

試料（A）について内圧負荷状態で外表面に急冷によ る熱衝撃を与え,びん破壊時の内圧及び熱衝撃 (温度差) を測定した. その結果を図 8 亿示す. 図 8 亿示した内圧 一熱衝撃関係のグラフ群から，累積破損率50\% における 内圧と温度差の関係を求めてみると，図９に示すような

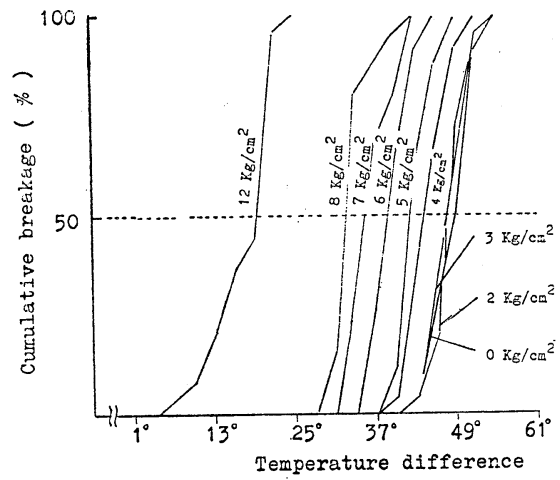

Fig. 8. Effect of internal pressure on thermal shock fracture.

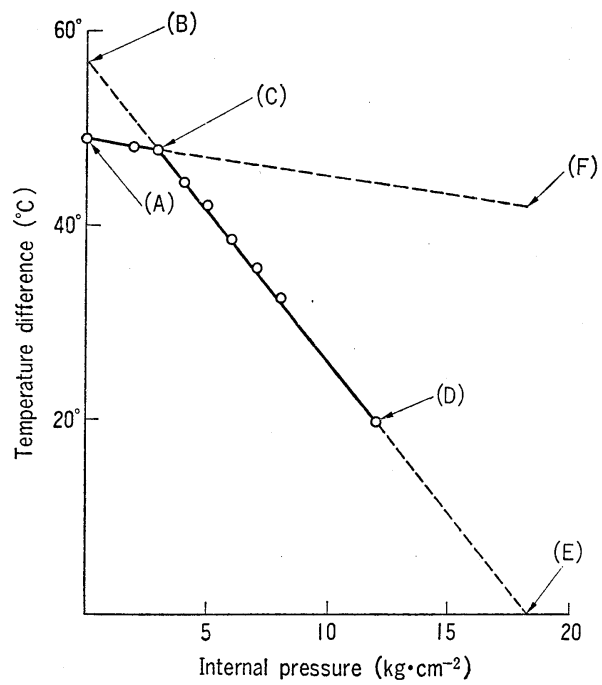

Fig. 9. Plot of internal pressure vs. temperature difference at cumulative breakage of $50 \%$ from Fig. 8.

(Note) Broken line : Line of supposition, Solid line : Line of measurement.

結果が得られた. 図 9 から明らかなように内圧 $3 \mathrm{~kg} ・$ $\mathrm{cm}^{-2}$ の領域と $3 \mathrm{~kg} \cdot \mathrm{cm}^{-2}$ 以上の領域では，内圧一熱衝 撃関係に明確な差異が認められた. すなおち 内圧 $0 \sim 3$ 


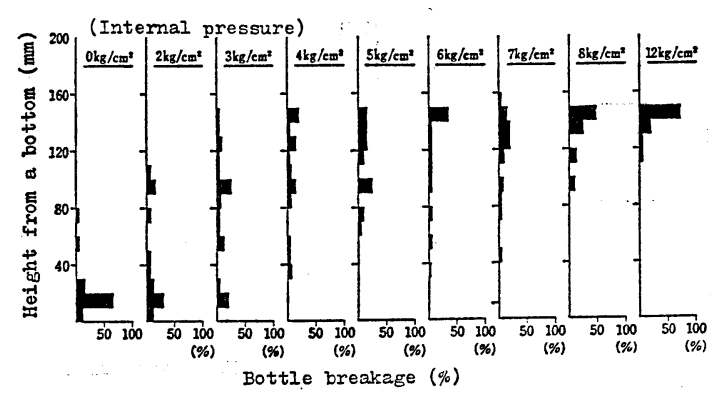

Fig. 10. Distributions of bottle breakage origins at internal pressure and thermal shock test.

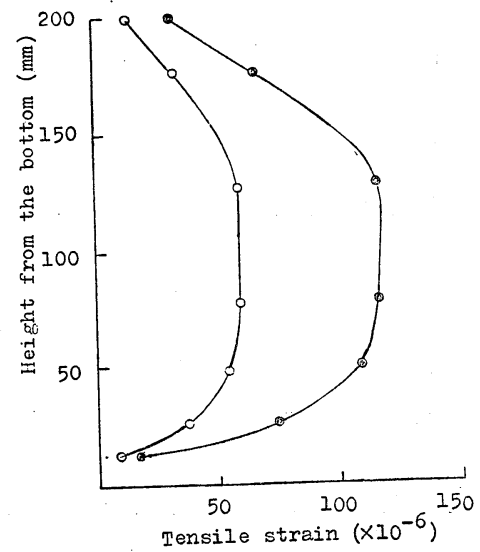

Fig. 11. Distribution of circumferential tensile strain of a test bottle under internal pressure.

$\circ \longrightarrow: 5 \mathrm{~kg} \cdot \mathrm{cm}^{-2}$,

$\cdot$ - : $10 \mathrm{~kg} \cdot \mathrm{cm}^{-2}$.

$\mathrm{kg} \cdot \mathrm{cm}^{-2}$ の領域ではややばらつきのある緩慢なこう配の 直線関係であり，一方 $3 \mathrm{~kg} \cdot \mathrm{cm}^{-2}$ 以上の領域ではこう配 が大きく, 明確な直線関係が認められた. この原因を解 明するため以下のような検討を行った.

まず破壊起点を調べてみると，図 10 に示すように内 圧 $0 \sim 3 \mathrm{~kg} \cdot \mathrm{cm}^{-2}$ の領域では，円筒下部（底より約 15 $\mathrm{mm}$ 高さ）に集中しており，一方内圧 $3 \mathrm{~kg} \cdot \mathrm{cm}^{-2}$ 以上 では内圧の上昇とともに漸次円筒上部へ移行し，底より 約 $140 \mathrm{~mm}$ 高さの位置に集中する傾向が認められた. なおこの位置は耐内圧強度において破壊起点が集中する 位置に対応している.

次に内圧負荷時にびん外表面の円周方向に発生する引 つ張りひずみをストレインゲージにより測定してみる と, 図 11 から明らかなように，底から約 $40 \mathrm{~mm}$ 高さ の領域までは底部の端末条件の影響を受けており，40〜 $150 \mathrm{~mm}$ 高さの領域では無限長さのガラス円管に近似し て考えてよいことが分った. また表面傷の集中している 円筒下部（15 mm 高さ）及び円筒上部（140 mm 高さ） について, 内圧により発生した円周方向の引っ張りひず み量を比較してみると円筒上部の方が下部に比べて約 7

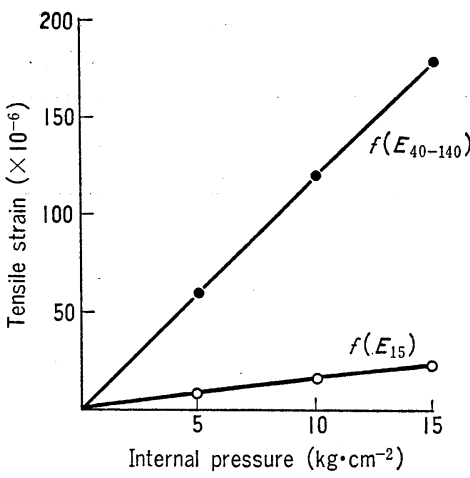

Fig. 12. Relationship between internal pressure and tensile strain of a test bottle.

$\circ \ldots f\left(E_{15}\right): 15 \mathrm{~mm}$ high from the bottom, - $f\left(E_{40-140}\right): 40-140 \mathrm{~mm}$ high from the bottom.

倍大きいことが分った (図 12 参照).

ところで破壊起点が円筒下部に集中する大気圧下での 耐熱衝撃強度は累積破損率 $50 \%$ における温度差として 約 $49^{\circ} \mathrm{C}$ (図 9 に打す $\mathrm{A}$ 点に対応) であり，破壊起点 の肉厚は約 $5.0 \mathrm{~mm}$ (表 1 参照) であった. 一方破壊起 点が底より $40 \mathrm{~mm}$ 高さ以上に存在し, 内圧 $3 \mathrm{~kg} \cdot \mathrm{cm}^{-2}$ 以上の領域における内圧一熱衝撃值線を延長したB点(図 9 参照）における温度差は約 $57^{\circ} \mathrm{C}$ であり，それに対応 する肉厚は約 $3.7 \mathrm{~mm}$ (表 1 参照) である.

なお Tooley ${ }^{192}$ によれば，ガラスに熱衝撃を与えた場 合に発生する引っ張り応力, $f(T)$ は以下のように表さ れる。

$$
f(T)=c \cdot \alpha \cdot \sqrt{D} \cdot \Delta T
$$

ここで, $c$ : 定数, $\alpha$ : 線膨張係数 $\left(9.5 \times 10^{-6}\right), D$ : 肉厚 $(\mathrm{cm}), \Delta T:$ 温度差 $\left({ }^{\circ} \mathrm{C}\right)$

(1) 式において $\Delta T \cdot \sqrt{D}$ の関係を図 9 の $\mathrm{A}$ 及び $\mathrm{B}$ 点 について計算すると，

$$
49 \sqrt{0.50} \div 57 \sqrt{0.37}
$$

となり，びんの底部と中央部で $c$ の值が大きく違わない と仮定すると, びん破壊時に A, B点において熱衝撃に より発生する熱応力はほぼ等しいといえる.したがって 大気圧下での熱衝撃にお゙いては，B点に比べて温度差が より小さくて破壊する $\mathrm{A}$ 点に破壊起点が集中するむのと 解釈できる。

次に負荷内圧が加わった場合について検討してみる. この場合図 9 に示すように熱衝撃による温度差 $\Delta T$ と内 圧 $P$ との間に直線関係が成り立つことから，内圧によ り発生する引っ張り応力, $f(P)$ と, 熱衝撃 (温度差) により発生する引っ張り応力, $f(T)$ の和 $f(P, \Delta T)$ に ついて考えてみる.

$$
f(P, \Delta T)=f(P)+f(T)
$$

ここでは破壊起点の位置によって問題を二つに分けて考 
えてみる。

（i）破壊起点が円筒上部（40 140 mm 高さで，肉 厚約 $3.7 \mathrm{~mm}$ ) に存在する場合.

まず内压による応力 : $f\left(P_{40-140}\right)$ についてみると, 図 11 から明らかなように無限長さの円筒の場合を考えれ ばよく，次式 ${ }^{20)}$ を用いることができる.

$$
f(P)=\frac{2 r_{\mathrm{i}}^{2} \cdot P}{r_{0}^{2}-r_{\mathrm{i}}^{2}}
$$

ここで, $r_{\mathrm{i}}$ : 円筒部の内半径 $(\mathrm{cm}), r_{0}$ : 円筒部の外半 径 $(\mathrm{cm}), P:$ びん内圧 $\left(\mathrm{kg} \cdot \mathrm{cm}^{-2}\right)$

この (3) 式は図 12 におけるびん内圧引引張りひず み直線の $f\left(E_{40-140}\right)$ に対応している.

内圧のみによる破壊は図 9 の $\mathrm{E}$ 点に対応しており， $P=18.3 \mathrm{~kg} \cdot \mathrm{cm}^{-2}$ であるから，破壞応力は（3）式より 計算して,

$$
f\left(P_{40-140}\right)=164 \mathrm{~kg} \cdot \mathrm{cm}^{-2}
$$

なる值が得られた。

次に熱衝撃による応力, $f\left(T_{40-140}\right)$ についてみると, この熱応力のみによる破壊は図 9 の B 点に対応し, $\Delta T$ $=57^{\circ} \mathrm{C}$ である. また破壊応力は（4）式に等しいと考え てよいから，(1) 式から $c$ (定数) を計算すると,

$$
\begin{aligned}
& c=\frac{f\left(T_{40-140}\right)}{\alpha \cdot \sqrt{D \cdot \Delta T}} \\
& \doteqdot 5.0 \times 10^{5} \mathrm{~kg} \cdot{ }^{\circ} \mathrm{C}^{-1} \cdot \mathrm{cm}^{-2}
\end{aligned}
$$

なる值が得られ，(2) 式は

$$
2.89 \Delta T+8.96 P=164 \mathrm{~kg} \cdot \mathrm{cm}^{-2}
$$

となる.この式は図 9 に示した内圧 $3 \mathrm{~kg} \cdot \mathrm{cm}^{-2}$ 以上の 領域における $\Delta T$ と $P$ の関係を表している.

（ii）破壊起点が円筒下部 (15 mm 高さで, 肉 厚 約 $5.0 \mathrm{~mm}$ ) に存在する場合.

まず内圧により発生する 応力, $f\left(P_{15}\right)$ についてみる と,これは図 12 における $f\left(E_{15}\right)$ に対応しており，位 置的にみてびん底の端末条件の影響を強く受けており， もはや (3) 式の関係を満足せず, $f\left(E_{15}\right)$ は $f\left(E_{40-140}\right)$ の約 1/7 であるから，

$$
f\left(P_{15}\right) \doteqdot \frac{1}{7} f\left(P_{40-140}\right)
$$

なる関係があるとみてよい.

熱衝撃のみによる破壞は図 9 のA点に対応し， $\Delta T=$ $49^{\circ} \mathrm{C}$ である. Wま内圧 $3 \mathrm{~kg} \cdot \mathrm{cm}^{-2}$ 以下でのびん破壊時 の $P$ と $\Delta T$ の関係を検討してみると，円筒下部の破壊 強度は円筒上部と同じとみてよいから $164 \mathrm{~kg} \cdot \mathrm{cm}^{-2}$ で あり，(2) 式は（1）式及び（3）式から次のように示さ れる.

$$
164=\frac{1}{7}\left[\frac{2 r_{\mathrm{i}}^{2}}{{r_{0}}^{2}-r_{\mathrm{i}}^{2}}\right] \cdot P+5.0 \times 10^{5}[\alpha \cdot \sqrt{D}] \cdot \Delta T
$$

（8）式について， $r_{\mathrm{i}}, r_{0}, \alpha$ および $D$ について所定の 值を代入し， $P$ と $\Delta T$ の関係をプロットしてみると，

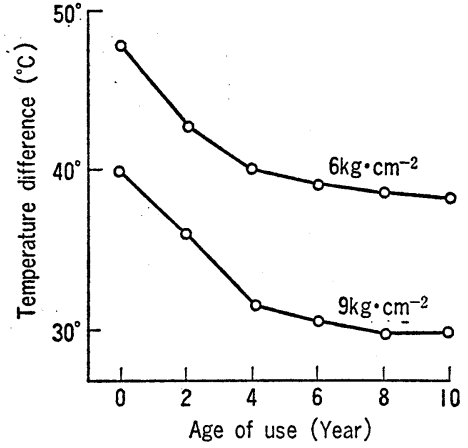

Fig. 13. Relationship between age of bottle use and the bursting strength and thermal shock strength.

(Note) Temperature difference shows a value at cumulative breakage of $50 \%$ at the internal pressure of 6 and $9 \mathrm{~kg} \cdot \mathrm{cm}^{-2}$, respectively.

図 9 に示すような $\mathrm{A}$ 点から $\mathrm{F}$ 点を通る直線が得られた.

以上の検討結果から試料（A）について内圧-熱衝撃 関係における内圧約 $3 \mathrm{~kg} \cdot \mathrm{cm}^{-2}$ を境にした直 線 関係の 差異が明らかとなった.

次に $\mathrm{E}$ 点（図 9 参照）について検討してみる.まず熱 衝撃 (急冷) によりびんが破壊するのに要した時間は急 冷後 $1 \sim 3$ 秒程度の瞬間的なむのであり， $\mathrm{E}$ 点は瞬間耐 圧值（加圧開始後 $1 \sim 3$ 秒で破壊する内圧值）に対応し ている.

ところで本実験において用いた内圧試験機は 1 分間持 続值（加圧開始後 1 分間で破壊する内圧值）として表示 され，試料（A）の耐内圧強度の経年劣化に関する図 2 のデータはこの 1 分間持続耐圧值として表示されてい る.

また Borchard ${ }^{14)}$ によればこの瞬間耐圧值と 1 分間持 続耐圧值の関係を検討して $100: 77$ というデータを出し ており, Sigwart ${ }^{21}$ 及び Schönbrunn ${ }^{22)}$ にれば約 100: 80 なる值を出している．本実験においては約 $100: 79$ (図 9 のE点と図 2 のデータの比較として) というほぼ 一致した結果が得られた。

1 分間持続耐圧強度が瞬間耐圧強度に比べてやや低い 原因は加圧の持続によるびんの静的疲労によるものと考 えられる。

\section{(2) 経年劣化}

試料（A）について耐熱圧強度（急冷による）の経年 劣化に関する検討をびん内圧 6 及び $9 \mathrm{~kg} \cdot \mathrm{cm}^{-2}$ の場合 について行った. その結果を図 13 に示す. 図 13 から明 らかなようにこの強度の劣化傾向は耐熱衝撃強度（図 6 参照）の経年劣化に類似したパターンが認められ，内圧 の負荷によって熱衝撃強度は大きく低下している.

ところでビール，サイダー，コーラなどの炭酸飲料び んにおいては, 熱殺菌時に最高 $6 \mathrm{~kg} \cdot \mathrm{cm}^{-2}$ 程度に内圧が 
上昇するため，充てん工場での熱殺菌工程で急激な冷却 は危険であり，急冷時の温度差の設定に当っては慎重な 検討を要することが分る.この場合にも本試験法が有力 な手段になり得ると考えられる.

\section{4. 総 括}

我が国において最を広く使用されているリターナブル びんの一つについて，各種強度の経年劣化を中心とした 検討を行った. その結果を要約して以下に示す.

\section{(1) 耐内圧強度}

びん破壊時の内圧 $(P)$ と破壊起点から伸びた割れ目 の分岐するまでの長さ $(L)$ の間には大まかに $P \cdot L^{1 / 2}=$ $c$ (一定) なる関係が認められた。 また内圧負荷時に発 生する引っ張りひずみ量はびん円筒部の棈円度に大きく 影響されることが分った。

\section{（2）耐熱衝撃強度}

急熱の場合は最高 $95^{\circ} \mathrm{C}$ まで熱衝撃（温度差）を与え ても，びんは全く破損しなかったところから，日常の取 り扱いで破壊する危険は非常に低いと考えられる.

急冷の場合はかなり低熱衝撃（温度差 $40^{\circ} \sim 50^{\circ} \mathrm{C}$ 程 度）で破壊するため，熱殺菌時あるいは冷水中への急冷 等は慎重に行う必要がある.

\section{（3）耐熱圧強度}

内圧負荷下でびんに熱衝撃を与えた場合，内圧 $0 \sim 3$ $\mathrm{kg} \cdot \mathrm{cm}^{-2}$ の低圧領域では，破壊起点はびん円筒下部の表 面傷帯に集中しており，一方 $3 \mathrm{~kg} \cdot \mathrm{cm}^{-2}$ 以上の高圧領 域では，破壞起点は円筒上部の表面傷に集中した。 また びん破壊時における内圧値と熱衝撃值の間には明確な直 線関係が得られた。

\section{文献}

1) F.W. Preston, Bull. Am. Ceram. Soc., 18, 35-60 (1939).

2) F.W. Preston, J. Am. Ceram. Soc., 23, 119-25 (1940).

3) J.B. Murgatroyd, J. Soc. Glass Technol., 26, 22-34 (1942).

4) J.C. Bowmaker and J.D. Gauwood, J. Soc. Glass Technol., 27, 22-26 (1943).

5) J.B. Murgatroyd, J. Soc. Glass Technol., 77-93 (1944).

6) H. Sigwart, Glastechn., Ber., 25, 276-85(1952).

7) L.H. Lehnert, Glastechn. Ber., 28, 259-62 (1955).

8) J.M. Teague and H.H. Blau, J. Am. Ceram. Soc., 39, 229-38 (1956).

9) E.A. Franke, Sprechsaal, 91, 229-35 (1958).

10) G. Schönbrunn, Glastechn. Ber., 38, 329-33 (1965).

11) J.M. Teague and H.H. Blau, J. Am. Ceram. Soc., 39, 239-52 (1956).

12）横倉修一, 吉田明輝, 窯協, 91，196-98 (1983).

13) J.J.S. Lomax, Glass Technol., 24, 27-33 (1983).

14) K.H. Borchard, VDI-Zeitschrift, 82, 1461-63 (1938).

15) S. Yokokura, Rept. Lab. Kirin Brewery Co., Ltd., 24, 21-26 (1981).

16) S.M. Budd and W.P. Cornelius, Glass Technol., 17, 154-59 (1976).

17) S.M. Budd and W.P. Cornelius, Glass Technol., 20, 170-73 (1979).

18）例えば, W.C. Levengood, J. Appl. Phys., 29, 82026 (1958).

19) F.V. Tooley, "Handbook of Glass Manufacture", Ogden Pub. Co. (1953) p. 18-20.

20) 例えば, 野原石松, “圧力容器”, 共立出版社 (1972) p. 122-23.

21) H. Sigwart, Glastechn. Ber., 25, 276-85 (1952).

22) G. Schönbrunn, Glastechn. Ber., 38, 329-33 (1965).

論 文・Paper

\title{
$\mathrm{Nb}_{2} \mathrm{O}_{5}$ ¿ $\mathrm{Al}_{2} \mathrm{O}_{3}-\mathrm{CaO}$ 系化合物の固相反応
}

\author{
堀田憲康・斉藤夏風・松尾重友・松下 徹* \\ $\left(\begin{array}{c}\text { 新潟大学 工学部 } \\ * \text { 化学工学科 } \\ \text { 海道大学 } \text { 工学部 } \\ \text { 応用化学科 }\end{array}\right)$
}

$\mathrm{Nb}_{2} \mathrm{O}_{5}$ 焼結体と 5 種類の $\mathrm{Al}_{2} \mathrm{O}_{3}-\mathrm{CaO}$ 系化合物 $\left(3 \mathrm{CaO} \cdot \mathrm{Al}_{2} \mathrm{O}_{3}, 12 \mathrm{CaO} \cdot 7 \mathrm{Al}_{2} \mathrm{O}_{3}, \mathrm{CaO} \cdot \mathrm{Al}_{2} \mathrm{O}_{3}\right.$, $\mathrm{CaO} \cdot 2 \mathrm{Al}_{2} \mathrm{O}_{3}, \mathrm{CaO} \cdot 6 \mathrm{Al}_{2} \mathrm{O}_{3}$ ) 焼結体を重称合わせて拡散対とし, 大気中, $1225 \sim 1300^{\circ} \mathrm{C}$ で加熱し た. 生成する反応層を $\mathrm{X}$ 線マイクロアナライザー分析及び $\mathrm{X}$ 線回折により 測 定し, $\mathrm{Nb}_{2} \mathrm{O}_{5}$ と $\mathrm{Al}_{2} \mathrm{O}_{3}-\mathrm{CaO}$ 系化合物との固相反応を調べた.

$\mathrm{Nb}_{2} \mathrm{O}_{5}$ と $3 \mathrm{CaO} \cdot \mathrm{Al}_{2} \mathrm{O}_{3}, 12 \mathrm{CaO} \cdot 7 \mathrm{Al}_{2} \mathrm{O}_{3}$ 及び $\mathrm{CaO} \cdot \mathrm{Al}_{2} \mathrm{O}_{3}$ との反応においては，これら $\mathrm{Al}_{2} \mathrm{O}_{3}$ $\mathrm{CaO}$ 系化合物中の $\mathrm{CaO}$ 成分が $\mathrm{Nb}_{2} \mathrm{O}_{5}$ 中へ一方拡散し, 3 種類の $\mathrm{Nb}_{2} \mathrm{O}_{5}-\mathrm{CaO}$ 系化合物 $(\mathrm{CaO}$. $\left.\mathrm{Nb}_{2} \mathrm{O}_{5}, 2 \mathrm{CaO} \cdot \mathrm{Nb}_{2} \mathrm{O}_{5}, 3 \mathrm{CaO} \cdot \mathrm{Nb}_{2} \mathrm{O}_{5}\right)$ が生成した. また, $\mathrm{CaO} \cdot 2 \mathrm{Al}_{2} \mathrm{O}_{3}$ 及び $\mathrm{CaO} \cdot 6 \mathrm{Al}_{2} \mathrm{O}_{8}$ との反 